\title{
Pilon Fracture: A Case Report of a 45-Year-Old Dental Technician
}

\author{
Pouya Mafi ${ }^{1}$, James Stanley ${ }^{2}$, Sandip Hindocha ${ }^{*}, 3$ and Reza Mafi ${ }^{4}$ \\ ${ }^{1}$ Hull York Medical School, Heslington, York, YO105DD, UK \\ ${ }^{2}$ Department of Orthopaedic Surgery, York Teaching Hospital, YO31 8HE, UK \\ ${ }^{3}$ Department of Plastic Surgery, Whiston Hospital, Merseyside, L35 5DR, UK \\ ${ }^{4}$ Department of Orthopaedic Surgery, Hull Royal Infirmary, HU3 2JZ, UK
}

\begin{abstract}
Pilon fractures are complex and difficult-to-treat fractures of the lower extremity that account for about $1 \%$ of all lower extremity fractures and up to $10 \%$ of tibial fractures. The injury is caused by high energy axial load either from motor vehicle accidents or a fall from height. The treatment of these fractures has caused controversy among surgeons due to mixed outcomes. Here we report a case of pilon fracture in a 45 year old male patient who has sustained the injury as a result of a fall from a height of approximately 12 feet. We describe why it is absolutely crucial that the patient is treated with external fixation initially and evaluate its merits and drawbacks as well as ways to minimize the complications associated with external fixation of open intra-articular distal tibial fractures.
\end{abstract}

Keywords: External fixation, internal fixation, k-wire, pilon fracture, open reduction.

\section{INTRODUCTION}

Pilon fractures are complex and difficult-to-treat fractures of the lower extremity that account for about $1 \%$ of all lower extremity fractures and up to $10 \%$ of tibial fractures $[1,2]$. The term Pilon, meaning hammer, was originally described by the French surgeon Destot in 1911 [3] and refers to the mechanism of the injury: resembling the impact of talus on tibia to that of a hammer on a nail. These are also termed plafond (French for ceiling) fractures in which the 'tibial plafond' is the ceiling of the ankle joint.

Pilon fractures are more common in men than women [4] and their incidence is on the rise probably due to higher survival rates in road and traffic accidents as a result of air bags $[4,5]$. The injury is caused by high energy axial load $[1,6]$ either from motor vehicle accidents or a fall from height. It has been reported that $20-25 \%$ of these fractures are open fractures causing complications for treatment through severe soft tissue injury and swelling $[4,7]$.

The treatment of these fractures has caused controversy among surgeons due to mixed outcomes. Here we report a case of pilon fracture in a male patient who has sustained the injury as a result of a fall (Table 2).

\section{CASE REPORT}

A 45 year old dental technician was brought into the Accident and Emergency department via ambulance following a fall from a height of approximately 12 feet. He sustained an isolated injury to his right lower leg. On examination there was an open fracture of the right distal

*Address correspondence to this author at the Department of Plastic Surgery, Whiston Hospital, Liverpool, UK L35 5DR, UK;

Tel: + 44(0)1244366265; Fax: +44(0)1244366265;

E-mail: hindocha2001@yahoo.com tibia with a flap laceration approximately $7 \mathrm{~cm} \times 6 \mathrm{~cm}$ minimally contaminated with the tibia exposed on the outside of the wound (see Figs. 1, 2). The deformity was confirmed as a comminuted fracture to the distal tibia on $\mathrm{X}$ ray (see Figs. 3, 4). There was no neuro-vascular deficit. The open wound was classified as a Gustillo Anderson type IIIa [8] due to degree of comminution and ability to close the wound - confirmed at time of surgery.

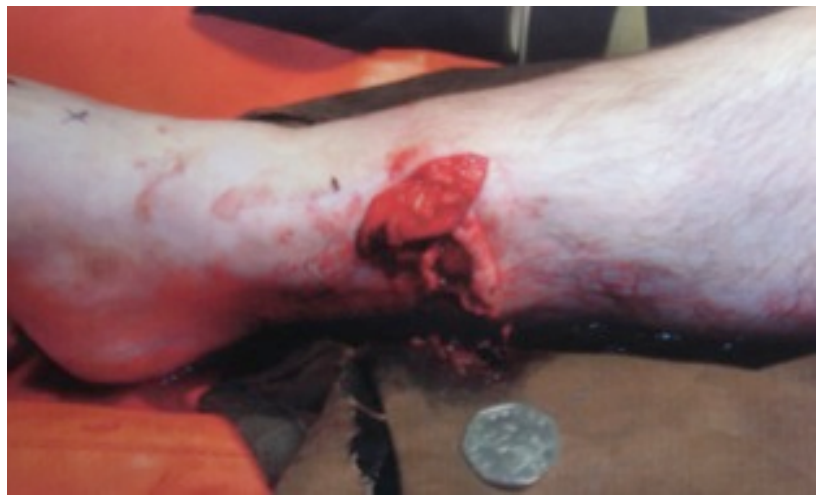

Fig. (1). A\&E picture 1, a 50p coin has been laid for comparison of the wound size.

\section{MANAGEMENT}

The patient was treated according to ATLS principles and confirmed the right lower leg as an isolated injury. The wound was dressed with antiseptic dressings and antibiotics started. A temporary above knee plaster back slab was applied. The patient was then expedited to theatre for wound debridement, lavage and stabilisation of the fracture with temporary external fixation (quadrilateral frame - Hoffman III) (Figs. 5-7). The skin flap was reduced with adequate bone coverage and sutured with 
non-absorbable sutures. The patient was referred to a tertiary centre for definitive fine wire frame fixation following CT scan.

\section{Table 1. Gustilo grade classification and definition.}

\begin{tabular}{|c|c|}
\hline Gustilo Grade [8] & Definition \\
\hline $\mathbf{I}$ & Wound $<1 \mathrm{~cm}$, clean \\
\hline II & $\begin{array}{c}\text { Wound }>1 \mathrm{~cm} \text { but }<10 \mathrm{~cm} \text {, no extensive soft tissue } \\
\text { damage }\end{array}$ \\
\hline III & $\begin{array}{c}\text { Wound }>10 \mathrm{~cm} \text {, extensive soft tissue damage, } \\
\text { typically high velocity injury }\end{array}$ \\
\hline IIIa & $\begin{array}{l}\text { Adequate soft tissue to cover fractured bone } \\
\text { available }\end{array}$ \\
\hline IIIb & $\begin{array}{l}\text { Soft tissue loss, periosteal stripping, usually } \\
\text { extensive contamination, need for soft tissue flap }\end{array}$ \\
\hline IIIc & $\begin{array}{l}\text { Fracture associated with arterial damage needing } \\
\text { repair with any degree of soft tissue damage }\end{array}$ \\
\hline
\end{tabular}

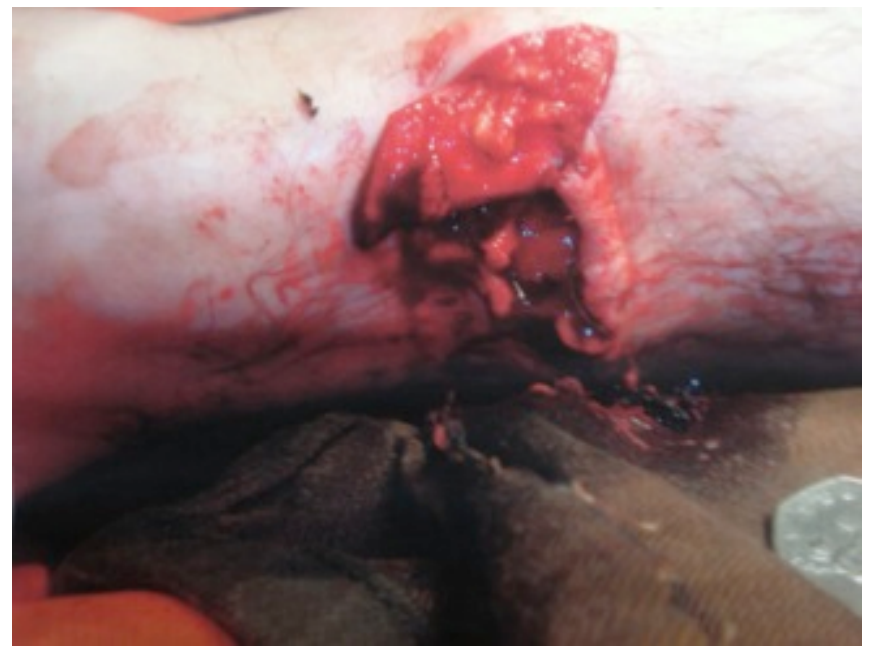

Fig. (2). A\&E picture 2, close up view of the open wound.

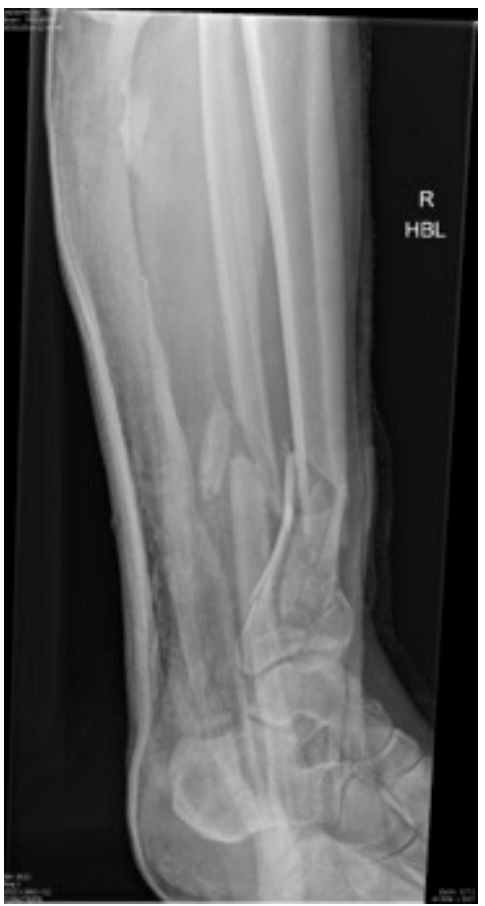

Fig. (3). X-ray 1, pre-op.

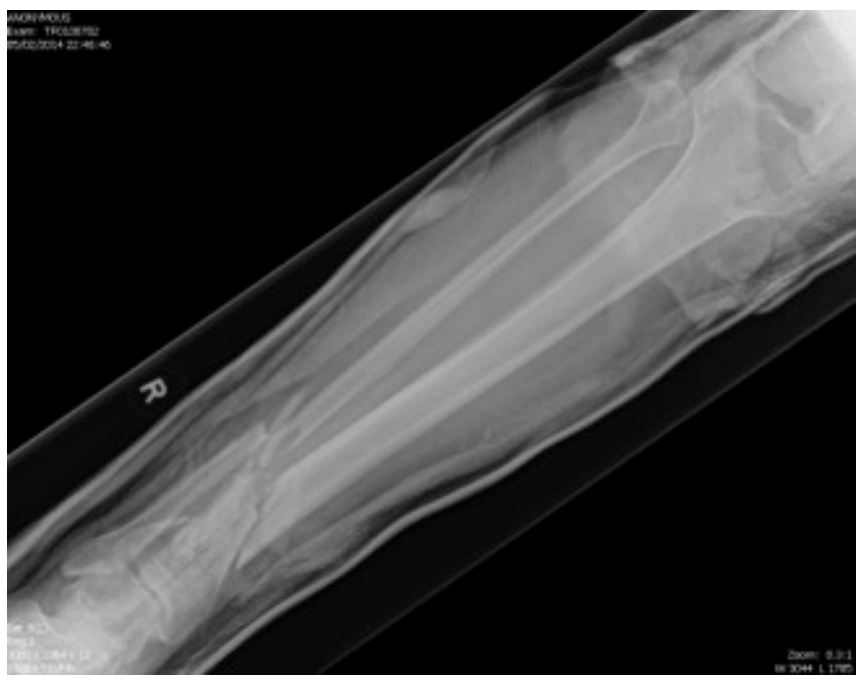

Fig. (4). X-ray 2, pre-op.

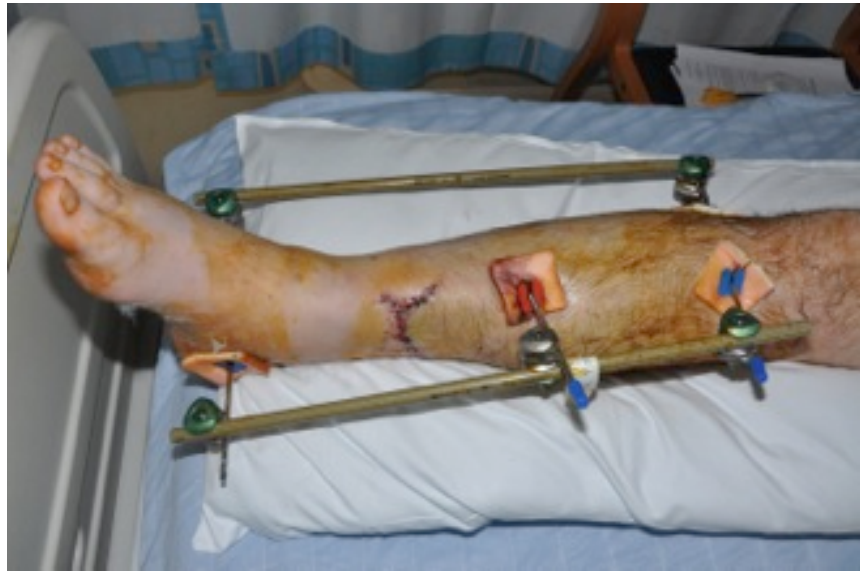

Fig. (5). Post-op picture 1, medial view.

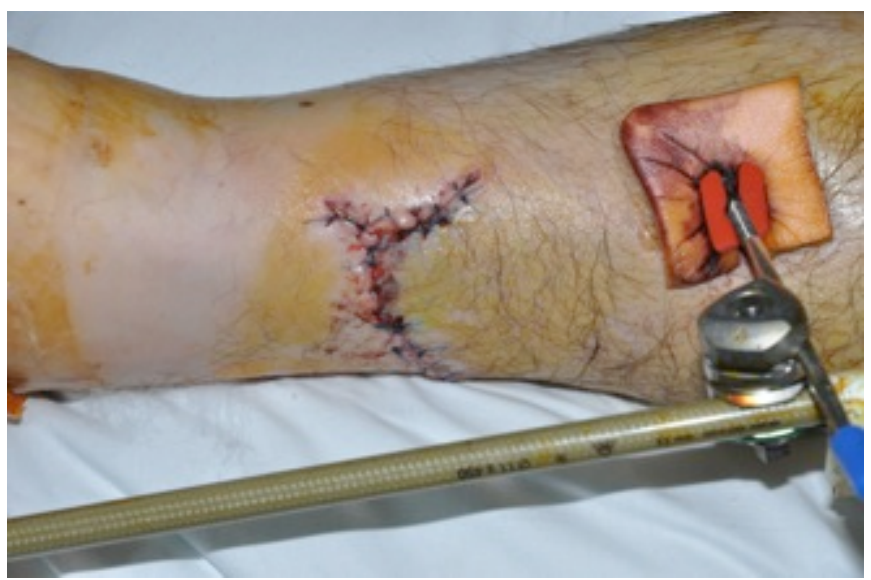

Fig. (6). Post-op picture 2, close up medial view.

\section{DISCUSSION}

Pilon fractures are notoriously hard to treat and have been a case for discussion for many years; historically often leading to amputation.

In low energy injuries, open reduction and internal fixation (ORIF) has proven to produce satisfactory results in terms of fracture union and ankle function $[1,2]$. Although 
Table 2. Comparison of merits and drawback of different treatment methods.

\begin{tabular}{|c|c|c|c|}
\hline & Plate (ORIF) & Standard Ex Fix & Fine Wire Ex Fix \\
\hline Advantages & $\begin{array}{l}\text {-allows weight bearing } \\
\text {-better fracture union } \\
\text {-early mobilization } \\
\text {-allows for visual reconstruction }\end{array}$ & $\begin{array}{l}\text {-allows access to site of injury } \\
\text {-rapidly performed } \\
\text { - no secondary insult to site of } \\
\text { injury. }\end{array}$ & $\begin{array}{l}\text {-Weight bearing } \\
\text {-early mobilization } \\
\text {-allows for limb lengthening } \\
\text {-allows correction of deformity } \\
\text {-minimally invasive and little soft tissue damage } \\
\text {-can be used both as first stage and definitive management }\end{array}$ \\
\hline Disadvantages & $\begin{array}{l}\text {-nerve, vessel, ligament, muscle } \\
\text { damage } \\
\text {-joint stiffness, numbness, weakness } \\
\text {-secondary insult to site of injury } \\
\text {-more time consuming to perform } \\
\text { than standard ex fix } \\
\text { - risk of deep infection }\end{array}$ & $\begin{array}{l}\text {-No weight bearing } \\
\text {-Mal union } \\
\text {-pin site infection } \\
\text {-delayed union } \\
\text {-does not allow for mobilization }\end{array}$ & $\begin{array}{l}\text {-technically challenging } \\
\text {-time consuming to perform } \\
\text {-high maintenance required } \\
\text {-superficial and deep pin tract infection } \\
\text {-frequent contact and close monitoring by the surgeon } \\
\text {-weight and bulk of apparatus }\end{array}$ \\
\hline
\end{tabular}

ORIF has the advantage of allowing the surgeon to visually reconstruct the joint it requires significant additional soft tissue injury during dissection. Plate and screw fixation is also extremely difficult with highly comminuted fractures as often seen in these high energy injuries with a significant risk of deep infection and wound breakdown [9].

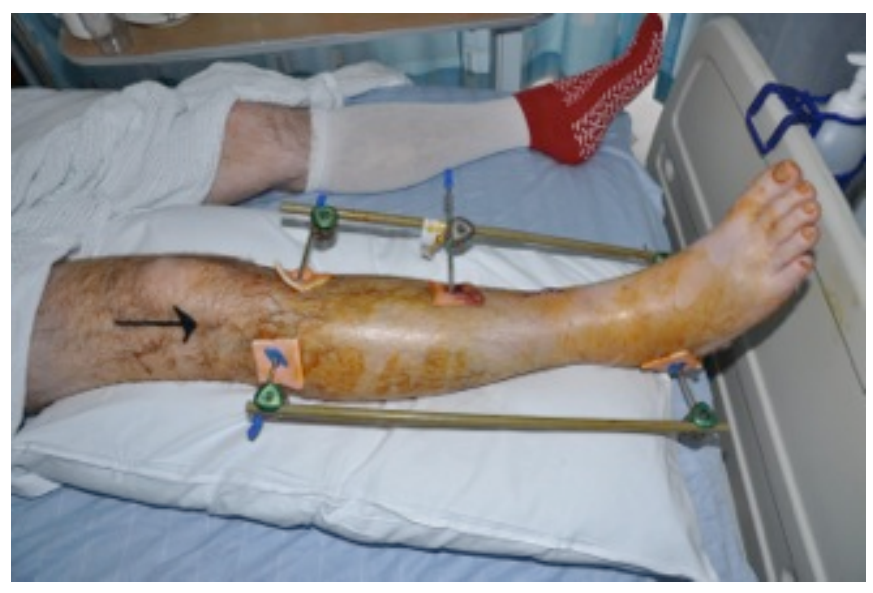

Fig. (7). Post-op picture 3, lateral view.

In this case the injuries sustained required stabilisation to prevent secondary soft tissue injury from fracture movement, and access to the wound for dressing and tissue viability.

External fixation allows secondary damage limitation through fracture stability with the additional benefit of surgical sites distant to the zone of injury (in this case transverse pins through the proximal tibia and calcaneum and a single pin mid tibia proximal to the soft tissue closed de-gloving area). Furthermore it is less time consuming to perform than an ORIF or fine wire frame and allows unimpeded access to the site of injury for vascular surgery, wound cleaning and wound checks.

The disadvantages of the standard type of external fixation is not inconsiderable, with potential problems including pin site infections [5], minor fracture movements causing non-union and inability to weight bear. Koulouvaris et al. found that in the long term follow up external fixation had a higher rate of delayed union and more reduction in activity in the subjects [10]. It is because of this that standard external fixation is rarely used as a definitive treatment and other methods such as ORIF or fine wire Illizarov type external fixators need to be considered.

In this case an ORIF is ill advised as the comminution and soft tissue injury are significant and minimising secondary injury is required. A fine wire Illizarov frame can be placed distant to the zone of injury and may allow for early mobilization and weight bearing (see Table 1). It requires however a specialist team for application and follow up as it is both technically challenging to apply and time consuming to maintain.

\section{CONCLUSION}

There are many options available to a trauma surgeon in treating complex periarticular open fractures. Understanding the injury and how the various treatment modalities may affect that injury are vital to reduce complications including amputation. In this case we have discussed the use of a standard external fixation followed by a fine wire fixation and the rational for that decision.

\section{CONFLICT OF INTEREST}

The authors confirm that this article content has no conflict of interest.

\section{ACKNOWLEDGEMENTS}

Declared none.

\section{REFERENCES}

[1] Kellam JF, Waddell JP. Fractures of the distal tibial metaphysic with intra-articular extension-the distal tibial explosion fracture. J Trauma 1979; 19: 593-601.

[2] Ruedi TP, Allgower M. The operative treatment of intraarticular fractures of the lower end of the tibia. Clin Orthop Relat Res 1979; 138: $105-10$.

[3] Destot E. Traumatismes du pied et rayons: X malleoles, astragale, calcaneum avantpied [in French]. Paris7 Mason 1911; pp. 1-10.

[4] Marsh JL, Saltzman CL. Ankle fractures. In: Bucholz RW, Heckman JD, Eds. Rockwood and Green's fractures in adults. $5^{\text {th }}$ ed. Philadelphia: Lippincott Williams and Wilkins 2001; pp. 205178.

[5] Burgess AR, Dischinger PC, O'Quinn TD, et al. Lower extremity injuries in drivers of airbag-equipped automobiles: clinical and crash reconstruction correlations. J Trauma 1995; 38: 509- 16. 
[6] Mockford BJ, Ogonda L, Warnock D, et al. The early management of severe tibial pilon fractures using a temporary ring fixator. Surgeon 2003; 1(2): 104-7.

[7] Ho K, Abu-Laban RB. Ankle and foot. In: Marx JA, Hockberger RS, Walls RM, Eds. Rosen's emergency medicine. $5^{\text {th }}$ ed. St. Louis: Mosby 2002; pp. 706-37.

[8] Gustilo RB, Anderson JT. Prevention of infection in the treatment of one thousand and twenty-five open fractures of long bones: retrospective and prospective. J Bone Joint Surg Am 1976; 58(4): 453-8.

[9] McFerran MA, Smith SW, Boulas HJ, Schwartz HS. Complications encountered in the treatment of pilon fractures. J Orthop Trauma 1992; 6: 195-200.

[10] Koulouvaris P, Stafylas K, Mitsionis G, Vekris M, Mavrodontidis A, Xenakis T. Long-term results of various therapy concepts in severe pilon fractures. Arch Orthop Trauma Surg 2007; 127(5): 313-20.

Received: May 25, 2014

(C) Mafi et al.; Licensee Bentham Open.

This is an open access article licensed under the terms of the Creative Commons Attribution Non-Commercial License (http://creativecommons.org/licenses/by-nc/3.0/) which permits unrestricted, non-commercial use, distribution and reproduction in any medium, provided the work is properly cited. 